Disclosure: Dr. Tafti served on the scientific advisory board for UCB Pharma (Belgium); and received honorarium, travel funds, and research grants from UCB Pharma (Belgium) and the European Narcolepsy Network (EU-NN). Dr. Heinzer received speakers' honoraria from Resmed Inc. and support from the Lancardis Foundation. Dr. Haba-Rubio reports no disclosures.

Reply from the Authors: We appreciate the comments of Haba-Rubio et al. We agree that weight loss following bariatric surgery may affect migraine headaches through a variety of different mechanisms, including improvements in OSAS.

As Haba-Rubio et al. explain, OSAS is highly prevalent in patients presenting for bariatric surgery, ${ }^{3,6}$ OSAS resolves in most patients postoperatively, ${ }^{4,7}$ and migraine frequency is reduced in patients with OSAS treated with CPAP. ${ }^{5}$ However, we would like to clarify that all participants in our study underwent polysomnography preoperatively and were prescribed CPAP if needed.

Assuming that participants with OSAS used CPAP to a therapeutic level, improvements in migraine headaches after bariatric surgery may have occurred independent of improvements in OSAS. We also note that previous studies have shown that obesity is associated with increased migraine frequency, independent of snoring and sleep problems. ${ }^{8,9}$

Further research is needed to understand how OSAS influences the associations of obesity and weight loss with migraine frequency and severity. We hope that our study stimulates further study of the relationship between weight loss and migraine and potential underlying mechanisms.

Dale S. Bond, Rena R. Wing, Providence, RI

Disclosure: See original article for full disclosure list.

Copyright $\odot 2011$ by AAN Enterprises, Inc.

1. Bond DS, Vithiananthan S, Nash JM, Thomas JG, Wing RR. Improvement of migraine headaches in severely obese patients after bariatric surgery. Neurology 2011;76:11351138.

2. Peppard PE, Young T, Palta M, Dempsey J, Skatrud J. Longitudinal study of moderate weight change and sleepdisordered breathing. JAMA 2000;284:3015-3021.

3. Lopez PP, Stefan B, Schulman CI, Byers PM. Prevalence of sleep apnea in morbidly obese patients who presented for weight loss surgery evaluation: more evidence for routine screening for obstructive sleep apnea before weight loss surgery. Am Surg 2008;74:834-838.

4. Haines KL, Nelson LG, Gonzalez R, et al. Objective evidence that bariatric surgery improves obesity-related obstructive sleep apnea. Surgery 2007;141:354-358.

5. Kallweit U, Hidalgo H, Uhl V, Sandor PS. Continuous positive airway pressure therapy is effective for migraines in sleep apnea syndrome. Neurology 2011;76:1189-1191.

6. Sharkey KM, Machan JT, Tosi C, Roye GD, Harrington D, Millman RP. Predicting obstructive sleep apnea among women candidates for bariatric surgery. J Womens Health 2010;19:1833-1841.

7. Varela JE, Hinojosa MW, Nguyen NT. Resolution of obstructive sleep apnea after laparoscopic gastric bypass. Obes Surg 2007;17:1279-1282.

8. Scher AI, Stewart WF, Ricci JA, Lipton RB. Factors associated with the onset and remission of chronic daily headache in a population-based study. Pain 2003;106:81-89.

9. Bigal ME, Liberman JN, Lipton RB. Obesity and migraine: a population study. Neurology 2006;66:545-550.

\title{
CORRECTION
}

\section{Vitamin B12, cognition, and brain MRI measures: A cross-sectional examination}

In the article "Vitamin B12, cognition, and brain MRI measures: A cross-sectional examination" by C.C. Tangney et al. (Neurology ${ }^{\circledR}$ 2011;77:1276-1282), there is a typographical error in the third paragraph of the Discussion section. On page 1280, in the right-hand column, second paragraph, the fourth sentence should read "In a British cohort where mandatory folate fortification is not in place, a comprehensive set of vitamin B12 markers were examined in association with brain atrophy over 5 years in 107 older adults." The authors regret the error. 


\section{Neurology}

Vitamin B12, cognition, and brain MRI measures: A cross-sectional examination Neurology 2011;77;1773

DOI 10.1212/WNL.0b013e31823ba492

This information is current as of November 7, 2011

\section{Updated Information \&} Services

Permissions \& Licensing

\section{Reprints}

including high resolution figures, can be found at: http://n.neurology.org/content/77/19/1773.full

Information about reproducing this article in parts (figures,tables) or in its entirety can be found online at:

http://www.neurology.org/about/about_the_journal\#permissions

Information about ordering reprints can be found online:

http://n.neurology.org/subscribers/advertise

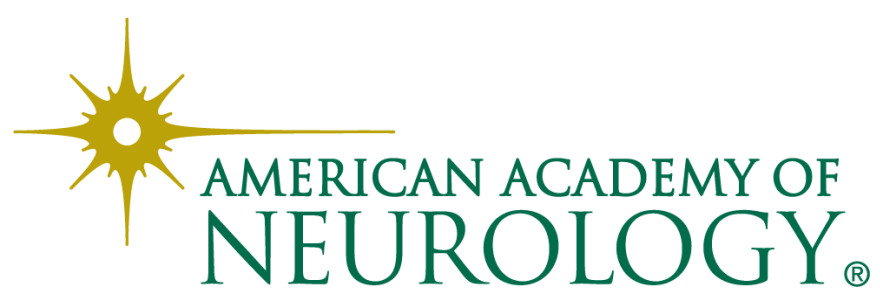

